\title{
West Seti Hydro-electric Project
}

The West Seti Hydroelectric Project (WSHEP) is a 750 MW storage scheme proposed by West Seti Hydro Limited on the Seti River in the Far Western Development Region (FWDR) of Nepal. The Project consists of a dam and storage reservoir, an underground power station, a switchyard and $400 \mathrm{kV}$ double transmission line for exporting the electricity to India.

The Project is classified by Asian Development Bank (ADB) as environment category 'A' primarily due to the magnitude of resettlement and the adverse impacts on land use and terrestrial and aquatic ecosystem. Snowy Mountains Engineering Corporation (SMEC) prepared a detailed Environmental Impact Assessment (EIA) report in seven volumes between 1996 and 2000. Government of Nepal (GON) approved EIA report in 2000. The EIA includes an environmental management action plan and resettlement action plan.

The structures of the Project are a $195 \mathrm{~m}$ high concrete faced rock-fill dam, 2060 hectare reservoir area, $\quad 6.7 \mathrm{~km}$ headrace tunnel, underground power station, $620 \mathrm{~m}$ tailrace tunnel, reregulation weir, switchyard, $20.3 \mathrm{~km}$ permanent access roads, and $132.5 \mathrm{~km}$

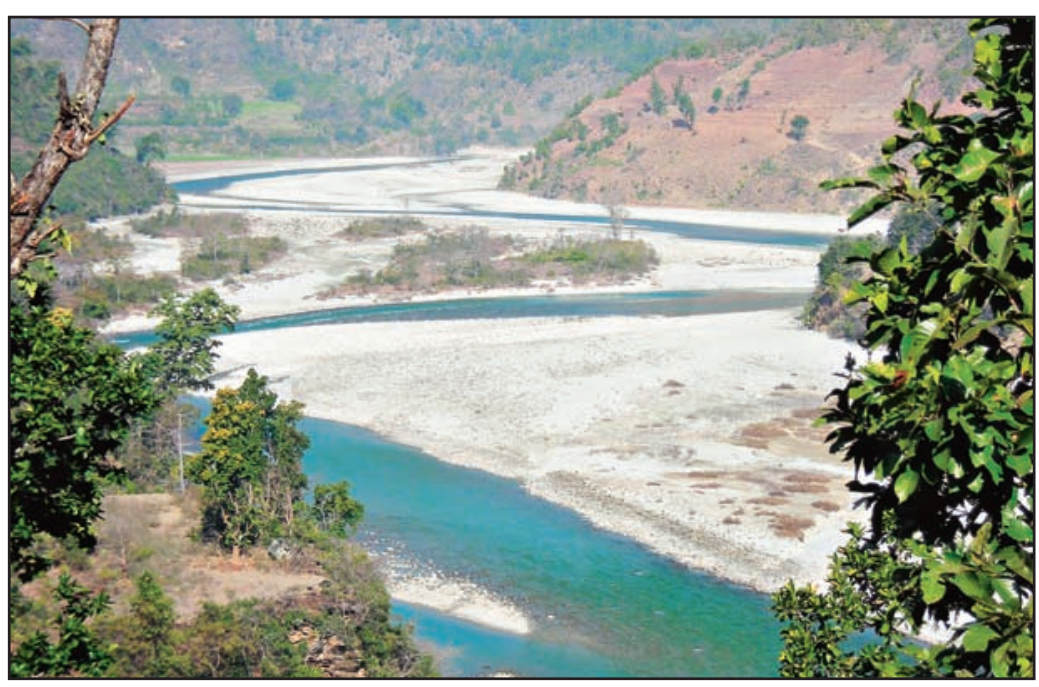

around a $19.2 \mathrm{~km}$ river section. The peak generation flow will be 330 cubic meter per second. The reservoir, having a total storage capacity of 926 million cubic meter of live storage and 640 million cubic meter of dead storage will inundate $25.1 \mathrm{~km}$ of Seti River and a total of $28 \mathrm{~km}$ of five main tributaries.

An estimated 1, 579 households and 12, 914 individuals will be resettled from the project site, with the majority of these requiring resettlement from the reservoir flood zone and no-habitation zone. The displaced households will be resettled to project relocation sites in the Terai compensating their lands and properties. The WSHEP has a plan to develop Terai resettlement sites on cultivated land purchased from larger landowners. In addition to compensation for asset losses, the Project will support resettlement and the restoration of livelihoods through the payment of various allowances, which include an evacuation/ $400 \mathrm{kV}$ double-circuit transmission line in Nepal; as well as permanent accommodation for up to 200 operation and maintenance staffs. Power Purchase Agreement has been done with Power Trading Corporation (PTC), India at flat tariff of US \$ 0.0495/ $\mathrm{kWh}$ up to 50 percent paid in the US dollars.

Power will be evacuated from the Project via 230.5 $\mathrm{km} 400 \mathrm{kV}$ transmission line. The initial $132.5 \mathrm{~km}$ of this line will be located in Nepal, running south from the switchyard to Attariya then west to Mahendranagar, with the final $98 \mathrm{~km}$ heading southwest in India to join the Indian electricity transmission grid at Atamanda, 22km north of Bareilly.

The project will generate power from a head of $259 \mathrm{~m}$, created by running the headrace tunnel across a river bend of the Seti River and thus diverting water estimated 38 percent of the households that are resettled to project relocation sites in the Terai who have land entitlements less than the defined minimum subsistence landholding. The project provides compensation for all affected household assets, and community resources and buildings, based on compensating for losses at replacement cost. The and livelihood of all those affected and provide resettled households the direct economic benefits.

The Project establishment would definitely involve the loss of private land permanently required. The land, comprising irrigated and rain fed cultivation land, is valued at $\$ 4.31$ million based on the appropriate price of land in the project area districts. The value of agricultural production that will be lost Project will restore or improve the living standards 
from this acquired land is estimated to be $\$ 1.55$ million per annum.

The projected budget of the WSHEP is US\$ 1.12 billion with investments from Snowy Mountain Engineering Corporation (26 percent), Asian Development Bank (15 percent), China National Machinery Import Export Corporation (15 percent), Infrastructure Leasing and Financial Services Ltd (15 percent), Special Purpose Vehicle (14 percent) and Government of Nepal (15 percent).

Besides 10 percent free energy, Nepal will get other direct benefits as energy royalty of $2 \%$ of the total project revenue over the first 15 years and 10\% thereafter, capacity royalty of NRs10o/kW per year for the first 15 years and NRs $1000 / \mathrm{kW}$ thereafter, export duty of $0.05 \%$, forest leasehold and land taxes, corporate tax on profits in accordance with Electricity Act 1992 and project dividends as a 15\% shareholder.

The project is a build-own-operate-transfer
(BOOT) scheme, through which West Seti Hydro has a 30-year generating license that will provide about 24.5 years of generation before full ownership of the project is handed over to the government. WSHEP will create 6,000 jobs during construction period with 200 permanent positions.

The constructing company SMEC signed a Memorandum of Understanding (MOU) with GON on 7 July 1994 for the development of WSHEP. However, only after 14 years i.e. on June 1, 2008 the West Seti Hydro Limited applied for generation license and transmission license to construct WSHEP, which is expected to begin in the near future.

Seen as the backbone of development of the people of the Far Western Development Region (FWDR) of Nepal, with the operation of the WSHEP, people from affected areas would be benefited from job opportunities, education, health, drinking water, electricity and other aspects of development. 